groups. MA Paulina Kowalska is the author of the article titled "The role of the United Nations Organization in the Process of Setting International Conflicts an the Turn of the $20^{\text {th }}$ and $21^{\text {st }}$ centuries". She claims the thesis solving disputes without UNZ support are impossible, in spite of its numerous defeats. Its activities are necessary in international politics. The next article titled "Political Conflict and its Exemplification in Today's Political Science in Poland" by PhD Renata Podgórzańska shows a wide scope of the discussed phenomenon. Its dynamics determine the social-political sytuations. The author gives an example of the dispute between the Law and Justice Party and the Civil Platform Party. Another view on the conflict is shown in the article called "Special Services in Military and Non-military Operations". The author writes about the military intelligence and counterintelligence and police activities during the peace, crisis and armed conflict. He discusses their activities aiming at asuring internal and external security of the state. The publication is closed by the article of Professor Andrzej Wojtaszak: Conflict and its Interpretation in a political context". He makes the coesistance of conflicts with political issues clear. The author presents the phenomenon of idealizing the enemy to gain the approval of public opinion for the ongoing activities. The authorities create a new picture of conflict giving themselves a strong positions in politics. It is one of the methods used today. Moreover the article shows an analysis of the conflicts and their solution methods.

The processes occurring these days require a flexible attitude towards the discussed issues. Therefore, there is a growing need for the publications which explain the current international situation. Thanks to the flexibility of the authors and the perfect subject selection, the above mentioned publication is a priceless source of knowledge. It lets us classify and systemize the information we have. The publication is bound to find many receipients among readers who are interested in the problems of contemporary conflicts and security.

\title{
Book review: P. Ebigg, R. Fiedler, A. Wejkszner, S. Wojciechowski, The Lexicon of Contemporary Terrorist Organizations, Istitute of Political Science and Journalism, Poznań 2007
}

\section{Wojciech Stankiewicz}

Terrorism is one of the greatest threats to contemporary civilization. The incidents that take the form of terrorist attacks occur in the territories of many countries, and they differ not only in motives and methods, but also in realization measures. These incidents continue to grow in numbers and escalate. In fact, terrorism paralyses huge masses of people and causes harm to the proper functioning of democratic countries, especially their eco- 
nomic, social and political institutions'. Rich countries are as much affected by it as those plunged in economic crises. Because of globalization, terrorists may freely travel around the world unnoticed by the most advanced identification systems.

The term "terrorism" means pre-meditated, politically motivated violence perpetrated against noncombatant targets by subnational groups or clandestine agents ${ }^{2}$. The origins of terrorism can be traced back to the emergence of organized state structures, which gave rise to the appearance of groups of people dissatisfied with the authority exercised over them. The causes of that complex process should be sought in political, ideological, religious, national, territorial, cultural, historical and socioeconomic determinants.

Recent intensification of this social pathology has resulted in numerous publications on the analyzed subject - majority of them concerning Islamic terrorism. It should, however, be remembered that terrorist organizations are not solely the domain of Islamic culture. Europe is also the area of activity of many organizations which use violence in the name of ideology. Among the best known are: the IRA (Irish Republican

1 K. Liedel, Zwalczanie terroryzmu lotniczego. Aspekty prawno-międzynarodowe, JURYSTA, Warszawa 2003, p. 56.

2 Country Reports on Terrorism 2005, Statistical Annex, National Counterterrorism Center, April 7, 2006, p. 9; US law requires the Secretary of State to provide the Congress (by April 30 ofeach year) a report on terrorism. Beginning with the report from 2004 the study called Country Reports of Terrorism replaced the previous Patterns of Global Terrorism.
Army), the ETA (Euskadi ta Askatasuna) an organization fighting for the independence of the Basque Country, or the $17 \mathrm{~N}$ group (Revolutionary Organization 17 November).

Poznań scientists have decided to prepare a publication dealing strictly with terrorist organizations. The Lexicon of Contemporary Terrorist Organizations is the first publication of this type in Poland, which analyzes about 100 widely known as well as marginal terrorist organizations from the whole world. The publication prepared by Piotr Ebbig, PhD, Radosław Fiedler, PhD, Artur Wejkszner, $\mathrm{PhD}$ and Prof. Sebastian Wojciechowski of Adam Mickiewicz University in Poznań has undoubtedly filled the gap on the Polish publishing market.

The Lexicon is a detailed compilation of contemporary active international organizations. The Lexicon entries describe the history, strategy, attacks and financing sources of the most important terrorist organizations. The selection of the organizations was based on the list published by the US State Department in $2006^{3}$. This is the most frequently used and the most complete classification in the world. Besides, the Lexicon has been drawn up in a very clear way. The introductory part explains all the definitions related to the subject and a list of abbreviations which facilitates understanding of the text. Individual terrorist organizations described in the monograph are presented in the alphabetic order. Additionally, the last

${ }^{3}$ Section 2656f(d) of Title of the United State Code, Country Reports of Terrorism 2005, op.cit., p.10. 
section of the reviewed book includes the list of organizations and the subject index which navigates the readers through terrorist organizations that are of interest to them. Furthermore, the Lexicon is supplemented with the bibliography section.

From among the terrorist organizations presented in the publication by the Poznan scientists I will, for the purpose of this discussion, select the most significant ones and classify them according to their motives into religious, liberation and ideological organizations. However, it should be borne in mind that my classification is theoretical, because frequently groups of this kind combine religion with the struggle for liberation or ideology.

Among religious terrorist organizations there are several dozen Islamic groups. In many cases they combine religion with the fight for the establishment of a religious totalitarian state.

The first of the analyzed terrorist groups is the Al-Jihad (Jihad Group, Holy War). The organization was formed in Egypt in the 1970s by a group of Islamic extremists aiming to overthrow the secular government and replace it with an Islamic state. The Al-Jihad is responsible for a number of terrorist attacks on the lives of representatives of the most prominent Egyptian authorities and their foreign allies. In 1981, the members of the Al-Jihad murdered the President of Egypt, Anwar Sadat, in revenge for signing the peace treaty with Israel in Camp David in 1979.

Recently, the activity of the Al-Jihad has been abated as a result of intelligence actions aimed at its leaders Abbud al-Aumar and the
Sheikh Umar Abd-Al Rahman. This, however, has not broken up the organization.

An important role in the religious and liberation struggle is played by the Al-Aqsa Martyrs Brigades. The organization was set up in September 2000. Its ideology and strategy is connected with Palestine's struggle for liberation from the Jewish occupation. One of the key group leaders was Maruan Barghouti (captured by the Israeli and tried for terrorist activity), who was responsible for the organization's activity on the West Jordan Bank. National liberation and religious motives are all present in the raison d'etre of the group. Suicide attacks are the main and the best known militant tactics of the organization. Besides, the Brigades fighters carry out shooting attacks against Jewish targets in the occupied territories and liquidation of the Palestinians who collaborate with Israel.

Another organization presented in the Lexicon is currently the most widely known terrorist group, the Al-Qaida (the Base, the World Front for Combat Against Jews and Crusaders). The organization was set up in 1988 by Osama bin Laden. At first, the primary aim of the organization was the fight against the Soviet occupation of Afghanistan, and afterwards, the militant actions were directed at the United States of America for their cooperation with Israel. One of the first terrorist operations of the Al-Qaida was the bomb attack on American soldiers in Yemenian Aden in 1992. Within less than a year, in the attack on the World Trade Center in New York 6 people were killed and over 1000 were injured. In August 1998, two simultaneous bomb attacks against the American 
embassies in Kenya and Tanzania took place in which 224 people died, including 12 Americans, and over 5000 were injured. Other assassinations were carried out in the next years. In 2000, a suicide bombing of the American destroyer USS Cole in the Gulf of Aden, Yemen, was carried out. The bombing killed 17 soldiers and injured 39. The most tragic, however, terrorist operation in the whole history of the Al-Qaida took place on 11 September 2001. It involved hijacking by 19 terrorists of 4 American airplanes and suicide attacks on the World Trade Center in New York and the Pentagon in Washington. The total death toll from the attacks was 3000 people. Since 2001 the Al-Qaida has carried out several dozen more attacks. Despite attempts made by the governments of many countries (especially USA) to break up the Al-Qaida, its leader Osama bin Laden is still at large.

Another religious terrorist group is the Armed Islamic Group (GIA) which was formed in 1992. The reason for its formation was the nullification by the Algerian government of the results of the 1991 parliamentary elections, whose first round was won by the opposition Islamic Salvation Front. The decision of the Algerian government caused riots in which the GIA participated. With time, the group has become the main force organizing terrorist attacks against high-ranking representatives of the state; one of their victims was the President of Algieria, Mugamad Boudiaf, who was murdered in 1992. It is estimated that in the years 1992-1999 the GIA caused the death of about 100 thousand people, mainly the representatives of government and the forces of law and order, jour- nalists and intellectuals. Outside Algeria the organization has developed its cells in many European countries including France, Belgium and Germany. The current leaders of the GIA are Mustapha Bouiali, Djamel Zitouni and Anter Zouabri.

Many Islamic terrorist organizations are also active in Asia. One of them is the Harakat ul-Jihad-I-Islami/Bangladesh (HuJ//B), i.e. the Movement of Islamic Holy War/ Bangladesh. The organization was established in 1992. Its key demand was to convert Bangladesh into an Islamic state. The group's activity concentrates in the area stretching from the city of Chittagong to the Myanmarese border in Bangladesh. In order to achieve its goal, the HuJI/B has made attacks on progressive Islamic intellectuals, journalists and Bengali politicians. Funding of the $\mathrm{HuJI}$ comes primarily from Islamic states such as Pakistan and Saudi Arabia, and formerly from Afghanistan through Muslim non-government organizations in Bangladesh including Adarsa Kutir, Islamic Fund Al Faruk or Hataddin.

Similar demands to those of the HuJi are made by the Kumpulan Mujahidin Malaysia (KMM). Established in 1995, the group struggles for the establishment of a panIslamic state in Southeast Asia comprising of Malaysia, Indonesia and southern Philippines. The organization is tied to many terrorist groups active in the region, among others to the Al-Quaida. The KMM members have been accused, among other things, of possession of weapons, bomb attacks, assaults and planning of terrorist attacks on foreigners. Through its alliance with other terrorist groups in Indonesia, the KMM is 
also involved in attacks against Christians in Indonesia.

Another category of terrorist organizations includes armed groups active in the territory of one or more countries whose main objective is the struggle for liberation. In this category we find the established in 1971 by the Pakistan's Inter-Services Intelligence the Al-Badr Mujahedin. This group's purpose was the struggle for the freedom of Kashmir, liberation of a part of Jammu and Kashmir and their merger with Pakistan. Afterwards, they wanted to liberate all the Muslim inhabitants of the Indian sub-continent. The group members are responsible for suicide assassinations conducted in the territory of Kashmir. The group reacted very negatively to the declarations made by the President of Pakistan, Pervez Musharraf, to cooperate with the United States in the war against terrorism.

Another group which may be included in this category is the Army for the Liberation of Rwanda (ALIR). The organization first emerged in the middle of the 1990s and became the armed branch of the Party for the Liberation of Rwanda consisting of the Hutu tribesmen. The ALIR's main goal is to overthrow the Tutsi-dominated Rwanda government and seize power by the Hutu. In 1999, the ALIR militants in protest against the American and British support of the Rwandan regime captured and killed eight foreign tourists including two American citizens. In March 2005, the group members announced their readiness to call truce and return to Rwanda. They also announced their willingness to carry out voluntary demobilization and repatriation to the country.
The next terrorist organization presented in the book is the East Turkistan Islamic Movement (ETIM). The group members advocate the creation of East Turkistan that would include portions of Turkey, Kazakhstan, Kyrgyzstan, Uzbekistan, Pakistan, Afghanistan and eastern China. The ETIM militants together with the Al-Qaida and Talibs fought against the forces of the Northern Alliance and pro-American coalition. American and Chinese sources indicate that the group is responsible for a series of terrorist attacks in the territory of China.

One of the most active terrorist organizations in Europe is the Euskadi ta Askatasuna (ETA) - Basque Fatherland and Liberty. The ETA was formed in 1958 as a group fighting for the autonomy of the Basque Country and the subsequent establishment of the Basque state on the Spanish-French border. The emergence of the ETA was associated with the nationalist views of one of its leaders Sabino Arana - who advocated the Basque race, religion, tradition and sovereignty. The first ETA operations were focused on planting bombs in Bilbao, Gasteiz, Santander in 1959. The most spectacular operation by the ETA was a successful bombing attack on the Spanish Prime Minister, Admiral Luis Carrero Blanco, in 1973. The ETA's targets have not been limited to politicians and their associates; the terrorists have also attacked people involved in the construction of the nuclear power station in Lemoiz, and drug traffickers. The group is responsible for kidnapping and murdering judges, councilors, policemen, journalists, professors and businessmen. Recently, the ETA has organized a bomb attack on the Madrit airport in 
which 2 people have been killed and 26 injured.

However, it should be noted that the presented organization does not restrict its activity exclusively to military operations. Since the 1960s, the ETA jointly with the Basque National Liberation Movement has greatly influenced social, cultural and political life of the Basque Country. Despite numerous attempts of negotiations and periods of ceasefire, the organization continues to conduct military operations, mainly in the territory of Spain.

The other terrorist organization carrying on its struggle in Europe is the Irish Republican Army (IRA). It is assumed that the organization was established in 1916 when the Irish uprising broke out in an attempt to liberate from the rule of the British that had lasted since the 16th century. The British had controlled the area since the 12th century and managed to assimilate a part of the Irish population. The conflicts have exacerbated when Protestantism was declared the official religion of England. The actual inclusion of Ireland into the British Empire took place in 1801 following the suppression of another uprising. During the times of the British rule on this land, two political movements were born: the Home Rule consisting of the supporters of a limited state autonomy and federation with the monarchy, and the Irish Republican Brotherhood established in 1859. The party branch of the Brotherhood is the Sinn Fein ("We ourselves"). The Sinn Fein won the 1918 elections in Ireland. Its MPs sitting in the British House of Commons assembled their own parliament in Dublin (the so-called National Assembly).
In 1919, the reconstruction of the Irish state was proclaimed. Another goal of the IRA is the struggle for undivided and united Ireland, as the British Crown has divided the country into two independent autonomous districts: the Protestant district with the capital in Belfast and the Catholic district with the capital in Dublin. Presently, the IRA has suspended military operations to conduct talks with the government of Great Britain.

The last of the terrorist organizations carrying on a liberation struggle (although it is connected with religion) is the Hamas, i.e. the Islamic Resistance Movement. This is an organization of Islamic fundamentalists aspiring to establish a Palestinian state. The year 1988 is considered the year of the actual emergence of the Hamas. In that year the organization published its ideological credo calling for, among other things, the destruction of Israel and creation of an Islamic state. In 1989, the Hamas was made illegal by the Israeli authorities, and its leader, Sheikh Ahmed Jassin, was arrested. In 1996, the Hamas boycotted the parliamentary election held on the area of the Palestinian Autonomy, thus distancing itself from the agreement between Palestine and Israel. Within one year of this event there was a significant escalation of military operations. During that time the Hamas, in coalition with other groups, carried out 136 attacks killing 65 and injuring 344 Israelis. This tendency kept up in the following years. The number of assassinations did not decrease until 1999. The strategy of terror was resumed in 2004 when the attacks claimed the lives of 300 people and injured 1200. In 2006, the Hamas won 
the election to the parliament of the Palestinian Autonomy which resulted in the exacerbation of relations with Israel and abatement of stabilization efforts in the region.

The last category of terrorist organizations embraces paramilitary groups which espouse different ideologies. Often, these are extremely leftist organizations.

The first of such groups is the Anti-Imperialist Territorial Nuclei for the Construction of the Communist Combatant Party (NTA - PCC). The NTA is an extremist leftist group that emerged in an Italian province in 1995. The goal of the organization is the struggle against the American imperialism, which is reflected by the presence of the NATO forces in the territory of Italy. Moreover, the group members condemn the Italian foreign and internal policy with respect to workers' matters. The political views of the NTA members are close to the views advocated by the Red Brigades - a terrorist organization active in the territory of Italy in the 1970s. The main manifestation of the group activity are bomb attacks. Among the most spectacular was the attack of September 2000 on the offices of the Central European Initiative in Trieste, and the attack of August 2001 on the court building in Venice. Since the arrest of the group leader in January 2004, there has been no reports of the group's activity whatsoever.

Another terrorist organization active in Europe is the First October Antifascist Resistance Group (GRAPO). In 1975, the group began its campaign against the presence of the NATO and USA armed forces in the territory of Spain. The GRAPO has been involved in kidnapping, planting bombs and direct attacks. By the end of the 1990s, the death toll of their operations reached about 1000 people. In 2002, in a coordinated action of Spanish and French police, many of the group members were arrested, especially its leaders.

Leftist terrorist organizations have appeared on almost every continent. Around 1970 in Japan, the Japanese Red Army (JRA) was formed. Its main goal was to overthrow the Japanese government and monarchy and support the world's revolution. In 1974, the group conducted an action involving occupation of the French embassy in the Hague three members of the JRA took hostage 11 people and demanded that the French government releases Yutaka Furuya, one of the organization members. The government of France consented to their demands. In consequence, the terrorists have released the hostages and fled to Syria on a special plane. In the 1980s the group carried out several bomb attacks on American facilities. Presently, the organization has declared cessation of hostilities and commencement of struggle by legal means.

The last of the analyzed terrorist groups is the Revolutionary Organization 17 November $(17 \mathrm{~N})$. This organization started its activity soon after the military coup in Greece and overthrow of the constitutional monarchy. The group's terrorist activity intensified in the 1980s and 1990s when they carried our a series of attacks against American and British diplomats supporting the military regime. Almost 20 people were killed. The main objectives of the group include: removal of the American army from Greece, removal of the Turkish people from Cyprus, and making the Greek authorities withdraw from the NATO and the European Union. In 2002, the Greek 
police forces captured the $17 \mathrm{~N}$ leaders, which significantly weakened the organization.

Each of the listed organizations is presented in a concise and analytical way, from the historical background to the contemporary situation. The Lexicon will be of use to anyone interested in international matters, especially to the students of political sciences, including international relations, as well as to anyone looking for a modern tool to understanding one of the biggest problems of the contemporary world. The relevance of terrorism as a threat to the civilized world order is proven by the fact that this monograph is a part of the research project named "Domestic and International Aspects of Terrorism" and realized by an international team of political scientists, lawyers, sociologists, economists and historians.

\section{Book review: Bartłomiej Michalak, Protes Parties in Western Europe. Analysis of Political Relevance (Partie protestu w Europie Zachodniej. Analiza relewancji politycznej), Wydawnictwo Adam Marszałek, Toruń 2008, pp. 312}

\section{Alfred Lutrzykowski}

Protes Parties in Western Europe. Analysis of Political Relevance by Bartłomiej Michalak is a book that deserves attention of wide range of readers, who are willing to deepen their knowledge concerning transformations of contemporary party systems. It is political parties that since nearly two centuries are a phenomenon of European political life. In other parts of the world they bring attention of not only researchers, but also of constantly growing social groups. Today, political life of any society is hard imaginable without parties, its coalitions, contentions and conflicts as well as almost constant presence of parties' leaders and activists in everyday life of millions of citizens of big metropolis and distant provinces.

Political parties in their history went through a complicated evolution, becoming the main powers that activate and organize participants of the battle for state power or at least for possessing an authentic influence on it. In that time party systems have taken shape, which is more or less proper mapping of the social powers configuration as well as level of power of certain political parties. As the consolidation of national political systems went further party systems showed tendencies to petrify static configurations and to create processes among party relations' schemes.

However, the dynamics of political life has led to disturb the preserved-to-some-extent balance and (at the end) to changes of the inner mechanism and various (types of) political systems. In Western Europe some symptoms of party systems 'refreezing' appeared. One of its main causes leading to that type of change was presence on the political stage of the new factions, which were guided by various motives, and which began to aspire to active and direct participa- 